\title{
A compreensão da comunidade joanina em Raymond E. Brown
}

\author{
Orientador: Prof. Isidoro Mazzarolo \\ Pesquisador: Douglas Galdino de Nascimento \\ Fonte: $\mathrm{CNPq}$
}

Introdução

O objetivo dessa pesquisa é de apresentar uma releitura da situação das mulheres no movimento jesuano e nos primórdios do cristianismo, ou seja, algumas poucas décadas após a ressurreição de Jesus Cristo. O ministério das mulheres apresenta uma característica no perfil do discipulado e, segundo Lucas e João, um discipulado na fidelidade e na perseverança até as últimas consequências. As formas como elas entram na vida e na missão de Jesus são distintas, mas a forma como o seu seguimento é apresentado apontam sempre para um modelo fiel e radical.

\section{Objetivos}

Estudar a influência da teologia lucana em João, sobretudo, a presença das mulheres no ministério de Jesus tal qual podemos identificar de modo indelével nos evangelhos de Lucas e João. Para tanto, nos utilizaremos também à linha de pensamento teológico de Raymond Brown, para identificar o amadurecimento teológico presente na comunidade joanina. 